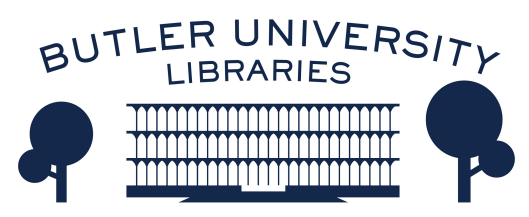

Journal of Hindu-Christian Studies

\title{
Book Review: "Spiritual But Not Religious? An Oar Stroke Closer to the Farther Shore"
}

Corinne Dempsey

Follow this and additional works at: https://digitalcommons.butler.edu/jhcs

Part of the Religion Commons

\section{Recommended Citation}

Dempsey, Corinne (2007) "Book Review: "Spiritual But Not Religious? An Oar Stroke Closer to the Farther Shore"," Journal of Hindu-Christian Studies: Vol. 20, Article 18.

Available at: https://doi.org/10.7825/2164-6279.1393

The Journal of Hindu-Christian Studies is a publication of the Society for Hindu-Christian Studies. The digital version is made available by Digital Commons @ Butler University. For questions about the Journal or the Society, please contact cbauman@butler.edu. For more information about Digital Commons @ Butler University, please contact digitalscholarship@butler.edu. 
been very theoretical in nature. While she includes the theoretical writings of Hindu law texts, such as the Laws of Manu, and the philosophical ideas of Sankara, Bhattacharyya's original contribution is to offer analysis in applied Hindu ethics focused on Assisted Reproductive Technology. This she does by utilizing her own clinical experience as a nurse, interviews with a few California Hindu informants and by applying the six elements of Hindu thought (drawn from the Mahabharata) to a real life contemporary case study - the 1995 birth of Jaycee Buzzanca as a result of IVF from anonymous donors, surrogacy gestations and birth under legal contract from the parents who divorce before the baby is born. The strength of this case study is that it highlights many of the legal and ethical challenges associated with assisted reproductive technology. Its weakness is that as the couple involved were not Hindu, the application of Hindu ethics remains at the level of theoretical extrapolation. Nonetheless, the real life legal and ethical issues raised by the case study are given an interesting and informative reading when seen through the Hindu lens of the Mahabharata narratives of Kunti, Madri and Gandhari in their struggles with infertility. It is to be hoped that Swasti Bhattacharyya will not stop here, as she does in this book, but will look for a case study of a contemporary Hindu family to analyze. Her clear thinking and writing demonstrate that she has the required theoretical and clinical knowledge to carry out such a task effectively.

Other than this desire for a further Hindu case study, my only criticism is that the comparison with Christianity is flawed by limiting the analysis to Roman Catholicism. While Bhattacharyya is careful to repeatedly emphasize that the Hindu tradition is very diverse and composed of many Hinduisms, her presentation of Christianity as Roman Catholicism in its most rigid and dogmatic form ignores the reality that Christianity too is very diverse. As a Protestant I felt shortchanged by this approach which made Christianity into a Roman Catholic "straw-man" that compared very poorly with the greater flexibility of the Hindu approach. The author's laudable sensitivity to the diversity of Hindu traditions needs to be sharpened to see the large diversity that exists within Christian traditions. As scholars now say, there are many Christianities. But, this comparative quibble aside, Bhattacharyya has written a clear, concise contribution to the Hindu Ethics of Assisted Reproductive Technology. It should be required reading for doctors, nurses and health care workers dealing with Hindu families struggling with infertility. The writing and thinking is so clear and carefully conceived that the book will also be helpful to Hindu families dealing with the problem.

Harold Coward

University of Victoria

\section{Spiritual But Not Religious? An Oar Stroke Closer to the Farther Shore. Reid B. Locklin. Collegeville: The Liturgical Press, 2005, 152} pp.

REID Locklin's Spiritual but Not Religious? represents a an unusual constellation of circumstances. Locklin wrote the book within a four-month period upon finishing his Ph.D. dissertation on the theologies of Adi Shankaracharya and St. Augustine of Hippo. With Shankara and Augustine still swimming in his head, Locklin reflects on his conversion to Catholicism, ten years prior, an event that surprised him and many others he knew. The crux of this surprise and an ecclesiological/theological issue with which Locklin's book grapples has to do with the fact that his allegiance to Catholicism cannot be separated from his affiliation with an institution that is marred (in a particularly grand way) by imperfection. Spiritual but Not Religious? is Locklin's thoughtfully variegated. response to a turn of phrase likely familiar to those reading this review, used by those who prefer to claim a 


\section{Book Reviews}

pristine spirituality unfettered by institutional religion. Locklin's aim is to offer - with substantial help from Shankara, Augustine, and inspiring figures from his own life story - a credible "spirituality of institutional commitment" that stands as a rebuttal to the book's title phrase. Locklin's presentation of this spirituality is framed, as he puts it, as gentle suggestion, as a "soft porch light" beckoning, in a humble tone befitting his youth that is, at the same time, carefully steered and informed by compelling and often profound intellectual and personal insights.

Locklin vividly weaves the intellectual with the personal throughout the book, featuring religious discoveries largely inspired by emblematic figures referred to as the Professor, Priest, Guru, and Guide. The book thus reads well for a broad audience; Locklin recounts his personal epiphanies in ways that invite the reader to accompany him as he reflects more deeply on the theological insights offered by them. He explores passages from Shankara, Augustine, the Upanishads, and the Bible in such a way that no one is left behind; he does not assume prior knowledge of pivotal concepts, deftly explaining them before engaging with his meatier points. The book's contribution to Hindu-Christian studies emerges from its engagement with comparative theology as well as its unique appeal for inter-religious dialogue. Locklin's journey is communal on a variety of levels; his discoveries are steered by an impressive list of personal and intellectual relationships that are, in turn, shared mindfully with a range of readers. This communal mode is a fitting framework from which to present his argument that the process of looking for, finding, and sustaining spirituality is best done in relationship with others.

In the book's first three chapters, Locklin builds a complex, sometimes pleasantly meandering, structure - supported by a range of analogies drawn from pop music, Rodin paintings, and team rowing in addition to autobiographical clips and passages from Hindu and Christian sources. Broadly speaking, the chapters lead the reader through the processes of seeking after religion, of teaching and learning the "language" of religion, and of understanding religious communion and community as indispensable to seeking and discovering spirituality. Among Locklin's astute and poetically delivered observations is the idea, discussed in chapter one, that seekers are often drawn to religion by disgust as much as desire, strong emotions that can represent two sides of the same coin. Locklin understands his initial, pre-conversion disgust at the institutional Church to have been entwined with his fascination with Catholicism. He argues for the many ways that disgust born of desire - or "beautiful garbage" - can undergird and propel us into conversion. Locklin's second, chapter addresses the importance of teachers and the sometimes-precarious issue of teaching authority. He likens the acquisition and sustenance of belief to that of language and friendship. The fluency of faith, like language, does not unfold through the memorization of doctrinal and grammatical rules, but through lived experience and interaction. Like friendship, faith requires not simply personal encounter but sustained commitment. Locklin thus argues that teacher-student interactions founded on commitment are a crucial means for building faith that, in the end, is inextricable from teaching authority. In chapter three's culmination of the prior two chapters, Locklin explores how religious institutions, constituted by a shared pursuit of a shared truth grounded in historical continuity, embody the idea that the highest goal cannot, on any level, be won alone. This does not deny the inevitable reality of institutional imperfection, but neither can imperfection remain the defining quality. Rather, Locklin argues, institutions are better understood as embodiments of a promise that is "both consolation in the face of failure and clarion call to do better in the future." Without this perspective we would be justified - and doomed - to perpetually wander from one community or religion to another.

Speaking of which, once Locklin guides the reader through the twists and turns of his position that spirituality is best nurtured by a balanced commitment to institutional religion, a journey that is simultaneously an exercise in Hindu-Christian comparative theology, he finishes his book by addressing a question that lurks behind many such endeavors. If, as demonstrated, Shankara and St. Augustine work 
equally well for supporting Locklin's argument, might this mitigate crucial differences between and religious commitment to particular traditions? Locklin's answer is complex and in many ways uncompromising. Although he considers himself a "theoretical inclusivist" and a "practical pluralist," he also feels both positions to be a little too clean and, more to the point, come with a cost to religious commitment. While inclusivist and pluralist views may soften institutional commitment, religious exclusivism; on the other hand, can reap disastrous results. The solution, as Locklin sees it, emerges within the realm of mystery. Bringing his book's argument full circle, Locklin notes that the mystery of inter-religious relationships, of the coming together of outsiders, as in any relationship, is central to the religious truths presented by both Shankara and Augustine. These theological mysteries, uniting apparent irreconcilables, echo the mystery of faith when conceived of as an encounter and relationship with an Other. The mystery and challenge of interreligious dialogue is thus not simply a biproduct of living in a shrinking global community but, as Locklin constructs it, the broadest of concentric circles surrounding the mystery and sacrality into which committed relationships propel us. The core mystery of faith as encounter with an Other, deepened and clarified by the challenges of institutional commitment, plumbs further depths with committed inter-religious exchanges - not interreligious conflations. As Locklin puts it, "if to be spiritual is to necessarily to be religious, then it is also true that to be religious is necessarily to be in dialogue."

Corinne Dempsey

University of Wisconsin - Stevens Point

\section{Fr. Bouchet's India: An $18^{\text {th }}$ Century Jesuit's Encounter with Hinduism. Francis X. Clooney. Chennai/Inida: Satya Nilayam Publications, 2005, pages viii +110}

IT is believed that as long as a person is remembered that person is not dead. One of the major challenges of a historian is not only to keep the memories of people alive, but also to recover and enliven the memories of those whose life and works were not remembered or forgotten. Whoever recovers these memories and provides them afresh to the contemporary generation of peoples deserve our congratulation. Father Francis X. Clooney, a Jesuit priest from New York, and the Parkman Professor of Divinity and Professor of Comparative Theology at the Harvard Divinity School in Massachusetts, has regained the memories of Jean Venant Bouchet (1655-1732).

Father Clooney's unique abilities to read and interpret the Tamil and French writings by Bouchet have enabled him to highlight the manifold contributions of Bouchet to the people of Tamil Nadu and Europe of his time. Originally, he went to Thailand, and desired to serve there. Sudden political changes forced him out of Thailand. He was a French Jesuit. Since 1689 he traveled extensively in the geographical area that is now known as Tamil Nadu, Andhra, Karnataka, and Kerala. He became a member of the celebrated Madurai Mission established by the well-known Jesuit missionary Roberto de Nobili (1577-1656), and lived mostly in Pondichery, the principal French Colony (1673/4-1954) on the southeastern Coromandel Coast of India. He learned the Tamil language and interacted with the Tamil people. They in turn appreciated his friendship and trust; therefore they disclosed to him the deepest aspects of their religious beliefs and practices, legal traditions, and socio-cultural behavior patterns. He learned not to compare the sociocultural settings of the Tamil people with that of the French or other Europeans; instead he recorded his observations and opinions that form the core of Father Clooney's present book.

Father Clooney masterfully examines Bouchet's letters written in French and his 